\title{
The Changing Tides of Volunteering in Development: Discourse, Knowledge and Practice
}

\author{
Erika Lopez Franco and Thea Shahrokh
}

\begin{abstract}
This article explores the changing narratives of volunteering in development and the interplay of volunteering with global and local theories of how change happens. Firstly, we analyse the links between the evolution of mainstream development trends and changes in volunteering approaches and programmes. Secondly, we look at how changing conceptions of volunteering have repositioned international volunteering in relation to national and local contexts. Thirdly, we present the implications of shifts in understandings of knowledge creation, which happens from the ground up, on volunteering research and programming. This discussion is situated within pressure for 'results' within contemporary development discourse and practice. The article concludes that the volunteering sector is at a crossroads; organisations working in meaningful partnerships with volunteers from local to global levels must remain at the forefront - questioning mainstream trends and advocating people-centred development. This article draws on a literature review undertaken to inform the Valuing Volunteering project.
\end{abstract}

\section{Introduction}

As part of the Valuing Volunteering research, a literature review was commissioned (Lopez Franco and Shahrokh 2012) with a twofold objective. Firstly, to provide contextual, academic and conceptual background information around volunteering and development. Secondly, as a resource that could become useful for future research into the impact of international volunteering. This literature review was initiated by International Forum for Volunteering in Development (Forum) members and other actors in the wider volunteering for development sector.

While conducting this review, the aim was to search for the literature focused on the volunteering for development sector; this uncovered two strands of research foci. Although there is a substantial amount of research on the evolution, impact, value and importance for society of the voluntary sector from various social sciences (Sheard 1995; Cnaan, Handy and Wadsworth 1996; Fyfe and Milligan 2003; Meijs and Brudney 2007; Hvenmark and von Essen 2010; Hustinx 2010); another area of focus is on volunteering within the development sector. The latter, excluding a few exceptions (Pinkau 1981; Devereux 2010; Patel et al. 2007; Lough et al. 2012), largely overlooks the fact that volunteering has been an integral part of human interactions and social dynamics before it became framed and used as an approach for achieving development outcomes.

Within the volunteering for development strand recent research has mostly focused on tracing the impact of international volunteering (Popazzi 2004; Moore McBride and Daftary 2005; Perold et al. 2011; Lough et al. 2012) with a very limited amount of research looking at the role of other forms of volunteering such as self-help and mutual aid, community participation (i.e. informal community-led volunteering) and national volunteering schemes. ${ }^{1}$ In addition, research has emphasised the impacts of engaging in volunteering action for the individual volunteer (Sherraden $e t$ al. 2006) and/or the volunteer-sending organisation, with a lack of research that focuses on Southern voices and how individuals in the South experience these different forms of volunteering. For example, how are volunteers perceived by the communities in which they are volunteering? How do volunteers, who are themselves from the poorest and most marginalised communities, experience volunteering?

Taking as its basis the findings from the literature review, this article will explore the changing narratives 

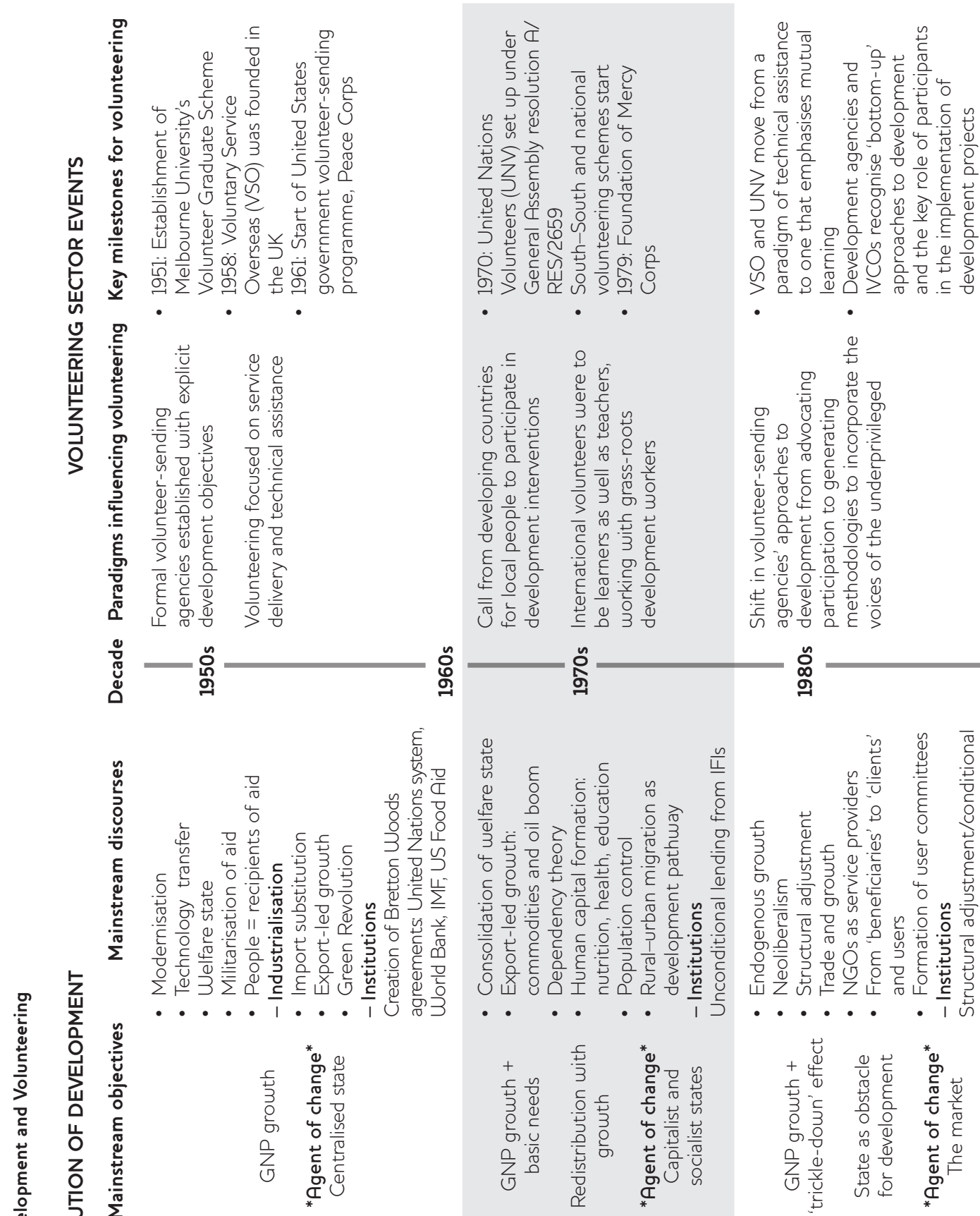

高
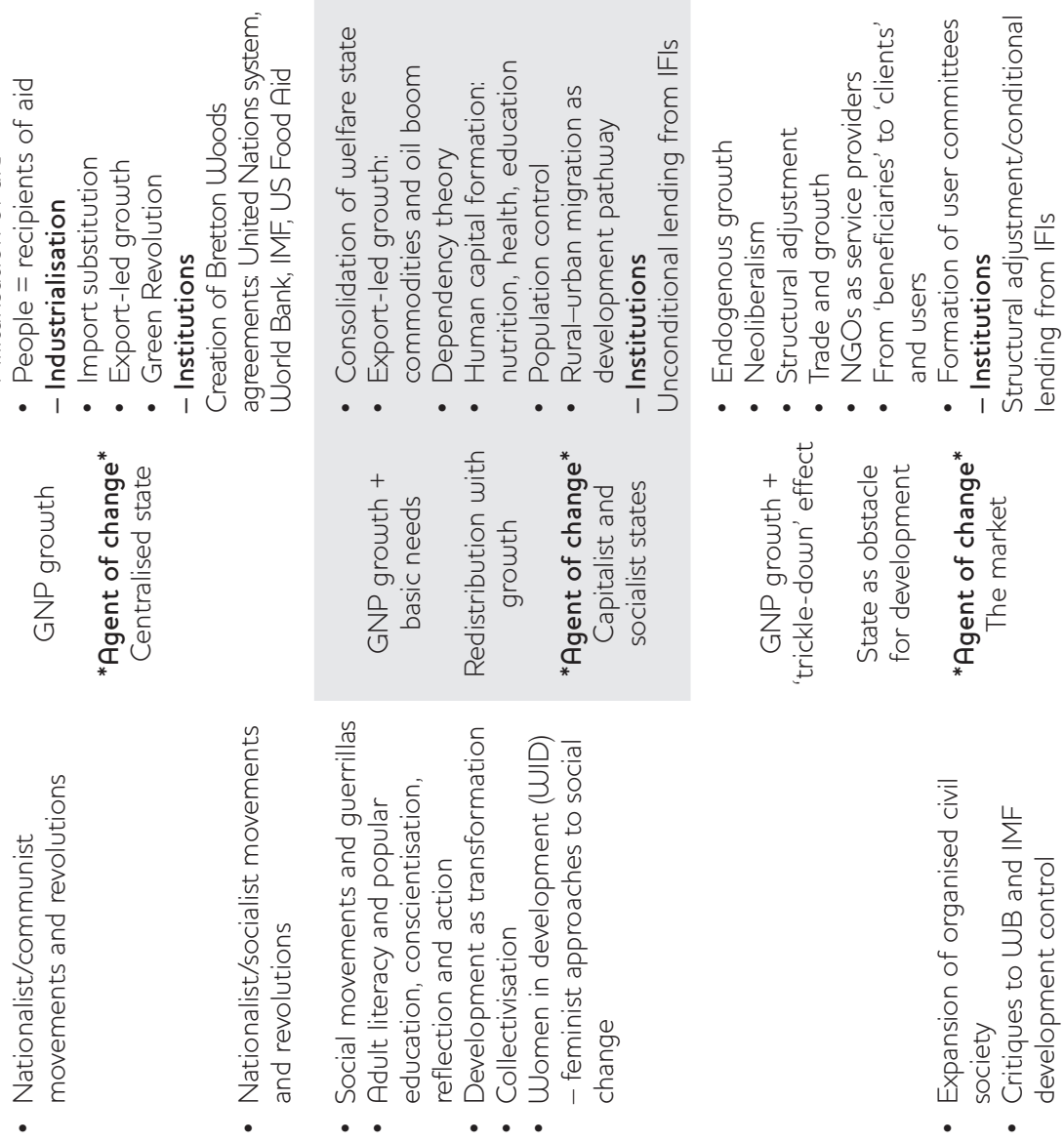


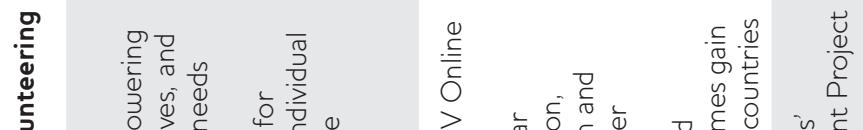

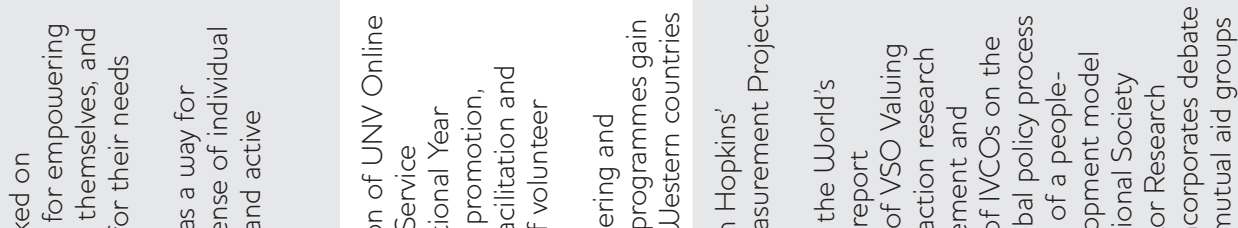

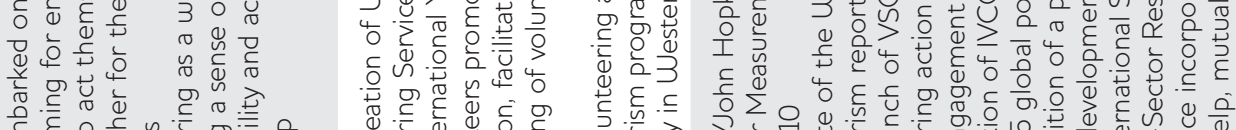

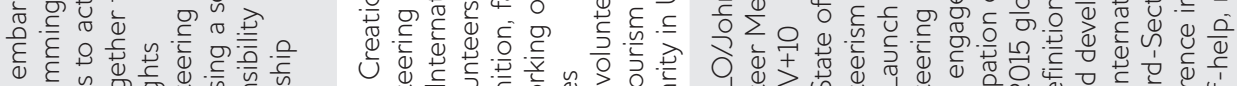

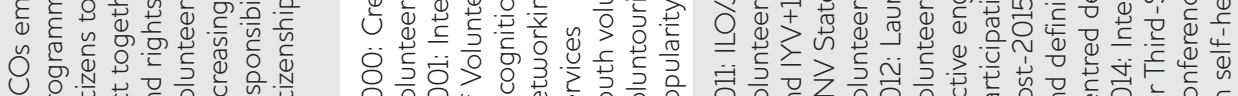

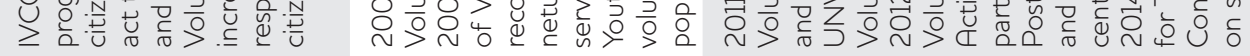

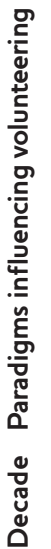

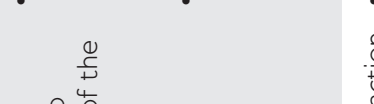

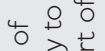

등 $\frac{\pi}{3} \frac{\pi}{2}$

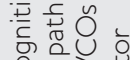

O

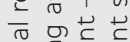

С

范造运

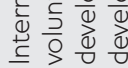

듬

\%ั

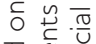

需 证

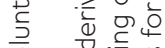

ये

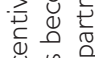

⿶.

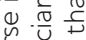

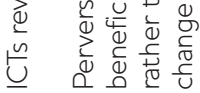

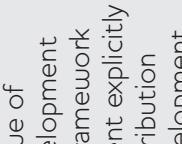

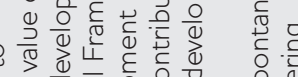

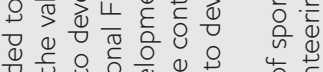

0

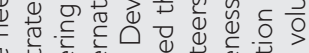

Q

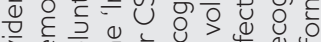

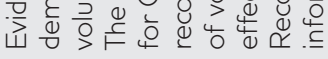

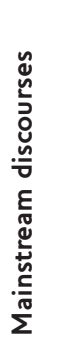

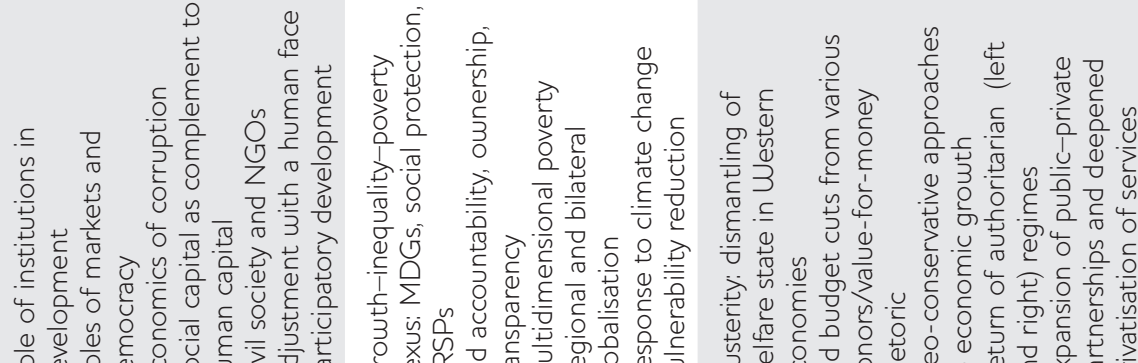

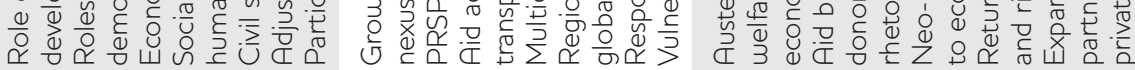

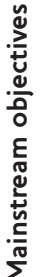
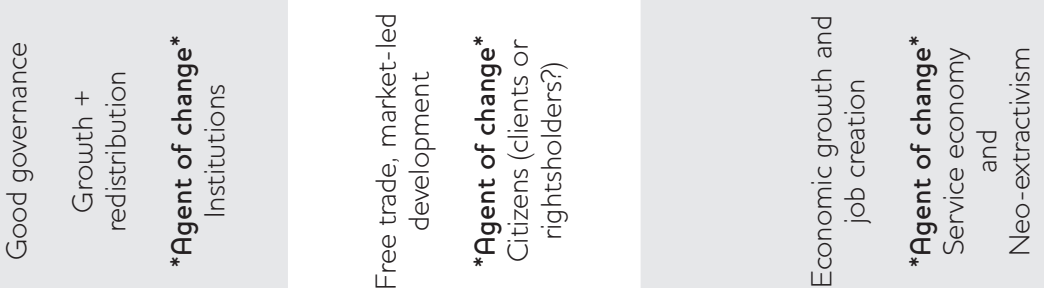

8

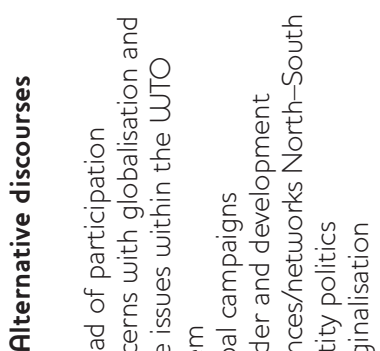

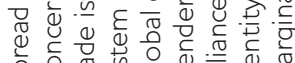

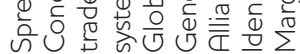

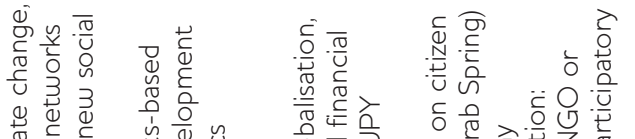

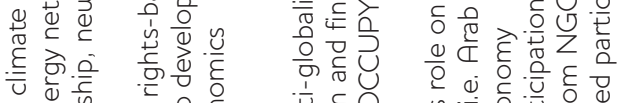

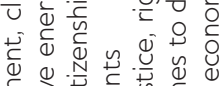

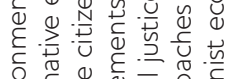

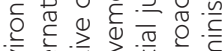

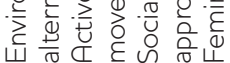

ह

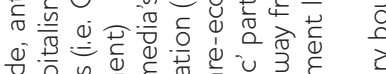

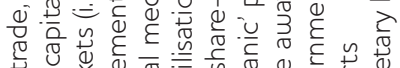

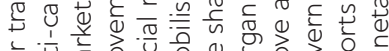

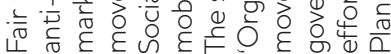

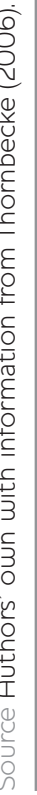


of volunteering in development and the interplay of volunteering with global and local theories of how change happens. Key questions we aim to answer are:

- How does the theory and practice of volunteering interact with the dynamics of development?

- How is this changing over time? Are trends and norms being renegotiated?

\section{Development discourse and approaches to volunteering}

The relationship between volunteering and development has evolved over time as trends in development paradigms respond to changing national and international contexts. Table 1 summarises some of the predominant shifts in development thought and practice (see Thornbecke 2006 for a full description from 1950 to 2005) alongside approaches to volunteering for development. The timeline outlines the historical trajectory, implicit theories of change, and agents of change driving the sector. The left-hand side of the table presents the mainstream discourses and objectives, as well as the alternative discourses that have shaped the development landscape since the 1950s. The right-hand side outlines shifts in approaches to volunteering for development.

The post-Second World War era and related processes of decolonisation saw changes in international relations towards globalised agreements, security agendas and the recognition of universal human rights. Globally, development became an aspiration to reach based on industrialisation processes, improved agricultural techniques (i.e. Green Revolution) and overall growth; all this mostly driven by centralised states. Within this context international volunteer cooperation organisations (IVCOs) emerged. The underlying assumption was that volunteers would transfer knowledge and practical experience not locally available or where it was under-resourced.

International development held a strong emphasis on the transfer of technical skills and knowledge inputs from the developed to the developing world. This skill-share model rests on the hypothesis that volunteers build the capacity of the receiving organisations, that those organisations are better able to meet their development objectives, and that this in turn brings about positive change for disadvantaged people; at the same time this is a mutual exchange of skills, experience and knowledge for the volunteer. ${ }^{2}$ In some ways, it also provided colonial nations a means of continuing engagement with the post-colonial world. For instance, international development agencies were established by the Swedish government in 1962, the Canadian government in 1959, and the United States government in 1961, to continue engagement with former colonies and partly in response to the emerging realities of the cold war. In some cases, ex-administrators of the colonies led these efforts (Moore McBride and Daftary 2005: 5).

The late 1960s and 1970s, considered as years of state-controlled development in both capitalist and socialist regimes, also saw the surge of alternative discourses to development. At the macro level, Southern thinkers spoke about countries at the core and the periphery of development processes; and from a nationalist position policies were enforced to establish growth through human capital formation and to ensure population control. Alternative movements emerged developing methodologies for critical engagement and recognition of oppression, inequality and marginalisation experienced by citizens, predominantly in the global South.

Freirian (1970) pedagogy of the oppressed enabled development to be seen as transformation, with action catalysed through the collectivisation of people. These progressive ideas were modelled in development programmes implemented by nongovernmental organisations (NGOs), recognising the role of people-led or bottom-up approaches. In international service, volunteers transitioned to become learners as well as teachers, working with grass-roots development workers within their placements (Moore McBride and Daftary 2005: 7).

The debt crisis of the late 1980s and 1990s, the end of the welfare state and emergence of neoliberalism equated to development as regards the liberalisation of markets, privatisation and unregulated investment. Mainstream development was fuelled by conditional loans from the World Bank and the International Monetary Fund (IMF) under the banner of 'structural adjustment'. At the start, the market was conceived as the driver of development and the state perceived as an obstacle; however, the persisting economic crisis up until the early 2000s shifted the emphasis from the free market economy to institutions as key to improving development outcomes. Towards the turn of the century, 'good governance' appeared as the pathway to development; relationships of accountability became increasingly visible as conceptions of citizenship and state-society relations gained prevalence. Development agencies and IVCOs increasingly recognised the need and relevance for engaging with local realities and underwent a 
transition from advocating participation to generating methodologies to include the voices of the most excluded in their programmes.

A consequence of deepening neoliberalism in global, national and local policymaking was the individualisation of the citizen as a consumer of services rather than a rightsholder. As a consequence, civil society organisations (CSOs) and wider social actors advocated for the deepening of democracy. The neoliberal framing was challenged, with citizens identified as holders of rights able to make claims upon duty-bearers (Jones and Gaventa 2002). IVCOs embarked on programming to empower citizens to act themselves and to act together for their needs and rights to increase their sense of individual responsibility and active citizenship (CIVICUS, IAVE and UNV 2007). This is deeply connected to the evolution of approaches such as South-South, diaspora and national volunteering, all designed to diversify the ways of engaging and reconceptualising the role of the volunteer as an agent of change and active citizen situated within local to global relationships.

The last ten years have witnessed a drive towards efficiency in development programming (i.e. aid effectiveness agenda) only to become more prominent after the 2008 financial crisis, which severely hit donor countries. Terms such as aid ownership, harmonisation, mutual accountability, results, and alignment with donors' requirements became widely known where established within the proliferation of global agreements on these issues. The civil society sector did not get overlooked in these global agreements; the 'International Framework for CSO Development Effectiveness' was adopted in June 2011 by CSO representatives from 70 countries; it explicitly recognised the contribution of volunteers to development effectiveness (Open Forum for CSO Development Effectiveness 2011). The Framework was later referenced in the Busan Partnership for Effective Development Cooperation, and adopted by the Fourth High-level Forum on Aid Effectiveness in November 2011. In practice, these agreements did not translate into better outcomes for those in most need. The emphasis on results, transparency, value for money, and accountability to taxpayers of aid-receiving countries - rather than local people (Haddad, Lindstrom and Pinto 2010: 6-7) - have generated perverse incentives for CSOs that are striving to meet key performance indicators, targets and milestones, rather than taking adequate time to understand the claims from the people on the ground and social change as a multidimensional, complex process. In turn, beneficiaries have become customers of the CSOs they relate to (Hvenmark and von Essen 2010) rather than partners for social change.

This current state of affairs and worldwide trends such as globalisation; individualisation; change of consumption, education and leisure habits; technological change; and growing demands for employability skills for youth have fostered the emergence of new ways to engage in volunteering activities (Jones 2008). Most of these schemes have developed volunteering on a short-term basis: voluntourism, ${ }^{3}$ clicktivism, ${ }^{4}$ corporate volunteering, youth volunteering. On the positive side, these trends represent an opportunity for people from diverse backgrounds, with diverse interests and characteristics to engage in volunteering (UNV 2011a: 26). On the downside, they often work only as palliatives or symbolic responses to deep-rooted problems and in some cases constrain people from engaging more deeply with structural change or long-term causes (Lopez Franco and Shahrokh 2012).

In recent years, the positionality of IVCOs has continued to shift and contributions to strengthening civil society and enabling and nurturing active citizenship, have become central in organisational visions for how change happens. The global policy process for defining a post-2015 development framework became a space where numerous coalitions of diverse organisations came together to advocate for a rights-based, people-centred approach to development in which the most marginalised groups take an active role in defining, implementing and monitoring those policies and programmes aimed to serve them (Beyond 2015 Campaign, CIVICUS, Participate, the IVCOs group, etc). However, the tension between 'individualisation and rights as service provision' versus 'collectivisation and rights as claims upon the state', continues to generate discrepancies among the various actors in the development sector from bilateral and multilateral donors to small community-based organisations (CBOs). The way an organisation perceives and relates to people will drive the theories of change behind their programming, advocacy, relationship-building and communications work (see Howard and Burns; Aked; Turner, this IDS Bulletin).

Volunteerism is a human act that dates before its conceptualisation within development programmes and interventions. The current research and policy environment is being driven to understand how and why volunteering is contributing to development 
outcomes. This analysis is critical for ensuring that there is accountability in global funding partnerships between donor governments, volunteer cooperation organisations and volunteers themselves involved in development programmes that work with and through volunteers. Within the assessment of the impact of volunteering, attention has been directed towards the international volunteer as a unit of analysis, which, as explored by Turner (this IDS Bulletin), has had important implications for how volunteering for development is positioned. Ensuring the cost-effectiveness and efficiency of the individual volunteer, for example, has limited how their role and position is understood in relation to wider processes of social change, from global to local levels. The negative outcome of this focus is that an exploration of volunteering as a catalyst of change that evolves from within communities, for example, and how this relates to social processes including civic and political action, has been marginalised from development framings.

\section{International volunteering, international service: turning the tide}

As seen in Section 2, it is evident that organised forms of volunteering have been deeply linked with the evolution and shifts in development paradigms and practice. Given the historical trajectory of international volunteering in development, this mode in particular can be taken as a standpoint from which to understand the dynamics of these changes. Furthermore, IVCOs are significant actors within the development sector, and have become the main channel through which funds are raised and allocated to programmes for volunteerism within development assistance.

Early framings of international volunteering schemes, as being designed to channel skills or resources to countries where these were lacking, have generated fierce critiques from development scholars that challenge the approach as merely a deepening of neocolonialism and paternalism, as outlined by Devereux (2008: 358): 'At its worst, international volunteering can be imperialist, paternalistic charity, youth tourism, or a self-serving quest for career and personal development on the part of well-off Westerners'.

Likewise, international volunteering interventions do not escape criticisms applicable to wider development project and programming approaches, such as: elite capture, being top-down and directive, generating patron-client relationships, being gender and culturally insensitive, perpetuating power imbalances, appropriateness to country contexts, and lacking accountability, among others (Chandhoke 2007). What therefore is needed to minimise these risks and ensure that international volunteering enables a positive contribution to social change? Devereux identified six criteria that were found common to effective long-term international volunteering interventions:

... humanitarian motivation; reciprocal benefit; living and working under local conditions; long-term commitment; local accountability and North-South partnership; and linkages to tackle causes rather than symptoms... The volunteers are accountable first to this local organisation and only more broadly to the agency facilitating their volunteer stint (2008: 359).

These characteristics relate to the length of the placement, the motivation of the volunteer, awareness of the local conditions, accountability to the local organisations rather than to external actors, the longer-term purpose of the engagement, and a sense of partnership rather than transferring expertise. With this in mind, IVCOs have structured international volunteering placements over the long term in order to avoid replicating the standard 'technical expert' model; intending to minimise the negative impact of the 'foreigner' in the community by encouraging the integration of the volunteer into daily activities and the local lifestyle. Moreover, wellestablished IVCOs have openly opposed the growing presence of voluntourism schemes driven by private companies, based on the assessment that benefits are biased towards the volunteer tourist, relationships are unaccountable to local people, and in the worst cases the volunteer is a burden to the community (Palacios 2010; Guttentag 2009).

IVCOs have also worked to create alternative models of volunteering such as South-South and diaspora volunteering which have given a new meaning to global volunteerism by challenging the North-South approach. This has been exemplified by the work of United Nations Volunteers (UNV), where since inception in the 1970s its volunteers have been predominantly South-South. Brown's assessment (2001) of South-South volunteering with IVCO programme officers and host organisations showed that volunteers were perceived as being well qualified and having valuable experience, particularly of working in local communities in a developing country setting. Kenya and the Philippines were the first two countries where VSO's South-South volunteerism pilot programme was conducted in 1999. Five years 
later, research by Popazzi (2004) found that 74 per cent of returned volunteers had been promoting volunteerism since finishing their placement, mostly by encouraging others to volunteer internationally or within their country. Furthermore, a large proportion of returned volunteers living in Kenya saw a practical role for themselves in contributing to community development. In an attempt to be more connected to local realities, and reflecting a shift in the global development sector more broadly, IVCOs have moved towards partnering with local CSOs to implement volunteering programmes and furthermore have increased their engagement with national volunteering schemes, often led by national and local governments. Although of course there will be divergent interests, with those most powerful in these relationships likely to dominate, these efforts towards transformation are an important catalyst for change in the wider volunteering for development sector.

At this point, IVCOs continue to face tensions in their relationship with other volunteer schemes such as corporate volunteering and youth volunteering. Research on international youth volunteering indicates an over-emphasis on the benefits to the volunteer over the local community. Evidence suggests that these projects can have a negative impact on the local community because young volunteers do not have enough knowledge, reflection capacity, skills, international experience, time or altruistic intentions (Palacios 2010; Brown and Hall 2008); or who are often in search of employability skills more than being able to contribute meaningfully. Research around youth volunteering has stated that even if it is done through long-term placements, it is important that organisations do not rely heavily on international youth volunteers; instead, organisations aiming at developing and/ or strengthening youth volunteering actions must put greater emphasis on encouraging national youth volunteering with elements of reciprocity (Scott-Smith 2011: 6, our emphasis). Ultimately, research has shown that careful structuring, coupled with socialjustice pedagogy are key elements to avoid negative results in short-term volunteering (Simpson 2004; Jones 2005; Aked, this IDS Bulletin).

Corporate opinions varied when asked about the significance of community benefit and volunteering. For some, ensuring that a difference was being made in the community is the very essence and reason for volunteering. For others, the business benefits in the form of employee engagement and skills development were more of a driver and achieving community benefit through volunteering, a bonus (Corporate Citizenship and VSO 2011). Further research led by the corporate sector found that corporations frequently justify programmes based on improved employee morale and contributions towards corporate citizenship (FSG, Pfizer and Brookings 2007). In addition to the issue of who benefits, there is a growing concern that in order to meet the interests of corporates, IVCOs and international non-governmental organisations (INGOs) have to 'bend' their programmes, particularly in a time where the third sector is increasingly struggling to find funding and the private sector is opening up in terms of social investment.

Despite the diversity of models and schemes of volunteering for development, 'volunteering' has a definition much broader than that tacitly given by the development sector (Dekker and Halman 2003). A study by Lukka and Ellis (2001: 43) exploring different cultural concepts of volunteering concludes that it means different things to different people, according to their social, cultural, historical and political positions. From a Western perspective, the term 'volunteering' occupies a paradoxical position. On the one hand, it lacks precision, as there is no clear-cut definition of what volunteering encompasses, and could be perceived as mere acts of generosity and care towards others (Sheard 1995; Handy et al. 2000). On the other hand, it has become narrowly defined in the minds of the general population by relating it to middle-class, suburban populations with spare money and time to share with a charitable organisation (Lukka and Ellis 2001: 35).

In their 2001 cross-national study Anheier and Salamon found that present trends of individualisation and secularisation are redefining volunteering: 'as a phenomenon, it is today ever less linked to religion, notions like "service to the nation" and traditional expectations, and tied more to specific needs, self-interest and greater individual choice (2001: 3). Expanding on this idea, Hustinx (2010) highlights the influential role of organisations in shaping the act of volunteering; through the way that they affiliate individuals, organisations invent new forms of social and civic relations making them more predictable and controllable. Hence, new organisational forms (of volunteering) are primarily not reflections of shifts in individuals' values, but a result of changes that occur at the intersections between individuals and institutions, and in that sense are not sustainable transformations. Additionally, programmatic approaches where volunteers are brought in to fulfil specific roles, which are designed 
to deliver services in order to meet a specific need, often subject to recruitment and management procedures, can generate a sense of disconnect and loss of purpose of the volunteering endeavour (Ellis Paine, Ockenden and Stuart 2012: 109).

The outcomes of these studies reflect the fact that the consolidation of a research and practice 'voluntary sector' has brought about the unintended consequence of having not recognised equally those non-programmatic volunteering endeavours such as self-help initiatives, cooperatives, support groups of different kinds and political movements where people organise to drive social change. Slowly, the call for linking volunteer programming to already existent forms of local voluntary action is gaining traction; at the present moment, there is a growing recognition from the IVCOs and of more grounded and organic forms of organising towards the achievement of diverse goals, not necessarily related to development sector framings. These diverse forms of volunteering have been explicitly recognised in a number of UN documents as part of the post-2015 and Sustainable Development Goal (SDG) processes (UNGA 2014; UNV 2014). However, there is room for deepening understanding about how formal (i.e. structured) volunteering programmes enhance rather than hinder these spontaneous endeavours.

\section{Shifts in knowledge power from global to local}

There is an important relationship between the emphasis placed on the 'international volunteer' in the volunteering in development sector, and theories of change regarding the impact of volunteering in development.

The individualised 'international volunteer' as a unit for analysis has intersected with pressures put upon IVCOs to demonstrate value for money; ultimately this has limited a more complex understanding of the role of international volunteers in the process of change (Lough and Matthews 2013). Success of IVCOs has therefore been measured in 'numbers sent' and an assessment of the economic value of volunteers in order to demonstrate why it is a costeffective way to solve certain development problems. This aim relates to the planning/efficiency agenda in which volunteerism advocates are searching for a justification for a particular policy/programme and looking at whether resources are being efficiently deployed (Archambault, Anheier and Sokolowski 1998). Although cost-effectiveness can be seen as an integral part of accountability in development programming, there is a growing real risk that over-investment in this area of assessment limits the understanding of how to strengthen volunteering for longer-term social development. Devereux (2008: 364 ) points out that virtually the only specific public opportunities for detailed reflection in busy, under-resourced IVCOs have been the mandatory donor reviews. Given the potentially damaging consequences of a negative report, these reviews were 'survived' rather than embraced as learning opportunities.

In recent years, however, as volunteering approaches have diversified and there seems to be a growing critical reflection on the question of who international volunteering serves, the nature of knowledge construction around volunteering and social change is also evolving. As has been analysed above, conceptions of the role of volunteering in social change are moving - albeit slowly and with drawbacks - from an emphasis on skills transfer and service provision, towards embedded learning and collaboration between international volunteers and partner organisations. This shift has been integral in bringing 'context' into the contributions of volunteering, and ensuring that the engagement of international volunteers is meaningful, relevant and accountable. Ultimately, as Hvenmark and von Essen (2010: 3) have discussed (based on reflections from Archer 1988, 1998 and Porpora 1998), both the possible contributions of voluntary work, and how we understand such a phenomenon, is to a large extent either enabled or impeded by cultural and structural conditions and features in the surrounding environment. Hence, ignoring these conditions will often result in negative consequences from the volunteering endeavour; these go beyond the individual characteristics of the volunteer (nationality, age, skill-level, etc) and relate to the relationships and partnerships built for mutual understanding (Hvenmark and von Essen 2010; Aked, this IDS Bulletin).

Participatory approaches emerged in the late twentieth century as an attempt to challenge top-down development planning, and in the process empower recipients of aid to reject the assumption that external 'experts' know best what creates the space for local knowledge to be assessed. The explanatory power of participatory forms of knowledge has been emphasised more recently in IVCO practice; for example, UNV alongside Forum members have undertaken a 'Participatory Methodology for assessing the Impact of Volunteering for Development' (UNV 201 lb). Lough and Matthews' (2013: 22) participatory research on the impact of international volunteering in the Kenyan context establishes that the relational 
contributions of volunteers as described by community members are integral for communitycentred development, which is often what is missed in more technical forms of development impact assessment studies. Furthermore, the systemic action research (SAR) methodology of IDS and VSO's Valuing Volunteering initiative enabled international volunteer researchers to explore how and why change is or is not happening in relation to volunteering through participatory and reflective methods (Burns et al. 2015). These methods enabled diverse volunteering actors and stakeholders to undertake complex analyses in an accessible and engaging way, and translate learning into action where spaces for creativity and experimentation within group processes were supported.

Participatory approaches can therefore both 'get under the surface of how communities operate, and how change happens' (Burns et al. 2015) and also enable the international volunteer to connect into alternative representations and practices in local settings and contribute to social change led by local people (Lewis, this IDS Bulletin; Hacker, this IDS Bulletin). Through such critical awareness, participatory approaches enable international volunteers to situate themselves as actors within the development process. In turn, there is potential for questioning implicit and explicit assumptions about expertise and impact of international volunteers in relation to other forms of local and indigenous initiatives. Participatory practice, therefore, has both transformative potential for the community and the volunteer. An interesting reflection in relation to pathways of change is the nature of the 'mobility' of international volunteers and the mobilisation of local knowledge to the global level as volunteers return to their home countries. This movement provides a platform to challenge norms and assumptions of international development assistance in donor contexts, as well as catalyse new forms of social action for the volunteer in their own everyday reality (Devereux 2008). As such, social change is not envisioned to happen exclusively where the formalised volunteering activity is happening; the transformative power of volunteering expands to domains which seem highly disconnected from local contexts but in reality are key to sustainable change.

\section{Conclusions}

Throughout this article we have provided an overview of the relationships and intersections between volunteering and development, and wider theories of change. Particular paradigms and intellectual trends within 'development' have seen the sector evolve, and at the same time geopolitical dynamics that structure social, political and economic processes from micro to global levels have shaped and reshaped development narratives. Volunteering as part of a development endeavour has not remained isolated from these wider shifts; its discourse and practice have evolved accordingly. As such, the 'international volunteer as expert' model that dominated the practice of volunteering for development for decades, is gradually changing.

However, within the mainstream collective imaginary the 'volunteer' still resembles a young middle-class expert. IVCOs and other INGOs continue to coordinate efforts to move away from this image and relate to organic forms of volunteering more meaningfully. In that regard, Valuing Volunteering outlined from the start the growing need to explore deeper 'change-oriented activism', particularly the relationship between volunteering, participation and social change, through the participatory SAR methodology. Moreover, practitioners and academics are increasingly moving attention from the international volunteer to non-programmatic volunteering endeavours such as self-help initiatives, cooperatives, support groups of different kinds and political movements where people organise to drive social change. As seen in this article, there is a growing recognition of the role of these structures in making 'external' volunteering programmes relevant and sustainable.

At this point, the volunteering sector seems to be at a crossroads. On the one hand, the continuous drive on value for money and demonstrating with quantitative 'evidence' the contribution of volunteers to development keeps pushing organisations and governments to focus on the quantifiable over quality and learning. On the other hand, it has become evident that formal and informal volunteerism has contributed to development at all levels, and shifts in the balance of power have been made possible where strategies and approaches have promoted principles of ownership, relevance and action for social change. At this point, IVCOs, through meaningful participatory practice, have challenged the assumptions of the outsider and 'expert' in development assistance, and are reconstructing and reframing the discourse of development as grounded in people's everyday realities rather than on headcounts in programmes. As we move forward in an increasingly complex global environment, it is critical that IVCOs retain these lessons and maintain their integrity within a people-centred paradigm of development and change. 


\section{Notes}

1 United Nations Volunteers has done this to some extent particularly focusing on researching, and planning national volunteer schemes with interested developing country governments around the world.

2 Sherraden et al. (2006) suggest a typology for international volunteering which divides firstly on the lines of building international understanding and intercultural learning, versus a service delivery model for development aid. The typology then divides international volunteers on the basis of duration, nature of service, and degree of 'internationality'. The first distinction between the 'soft' side of international understanding (e.g. fostering global awareness) and the 'hard' side of service delivery and development aid reflects the way in which donor aid agencies have often viewed international volunteering; most IVCOs do not promote such a dichotomy (Devereux 2008).

\section{References}

Anheier, H. and Salamon, L. (2001) Volunteering in Cross-national Perspective: Initial Comparisons, Civil Society Working Paper 10, London: London School of Economics

Archambault, E.; Anheier, H.K. and Sokolowski, W. (1998) 'The Monetary Value of Volunteer Time: A Comparative Analysis of France, Germany and the United States', paper presented at the Review of Income and Wealth Conference, Lillehammer, Norway, 18-24 August 1998

Brown, G. (2001) 'Southern Volunteer Programmes Learning Review of the "South to South" Pilot', VSO internal document, unpublished

Brown, F. and Hall, D. (2008) 'Tourism and Development in the Global South: The Issues', Third World Quarterly 29.5: 839-49

Burns, D. et al. (2015) Valuing Volunteering Final Report, VSO, www.vsointernational.org/sites/vso_ international/files/the_role_of_volunteering_ in_sustainable_development_2015_vso_ids.pd (accessed 15 July 2015)

Chandhoke, N. (2007) 'Civil Society', Development in Practice 17.4: 607-14

CIVICUS, IAVE and UNV (2007) Volunteering and Social Activism: Pathways for Participation in Human Development, www.unv.org/fileadmin/img/wvw/VolunteerismFINAL.pdf (accessed February 2012)

Cnaan, R.; Handy, F. and Wadsworth, M. (1996) 'Defining Who is a Volunteer: Conceptual and Empirical Considerations', Nonprofit and Voluntary Sector Quarterly 25.3: 364-83
3 'Voluntourism' refers to the tourism industry that has evolved to enable people to volunteer at the same time as going on a holiday. It has been said that for poor communities, voluntourism can be seen as another incomegenerating activity, providing increased human and financial resources, local employment and improved facilities (UNV 2011: 30-1). However, voluntourism has also come under harsh criticism. As the trip length decreases, the volunteering placements are designed more for the convenience of the volunteer rather than to support local community needs. In 2006, VSO made a public statement warning of the risk that the proliferating gap-year programmes might become a new form of colonialism, reinforcing an attitude of 'it's all about us' by their emphasis on short-term 'helping' over learning.

4 'The Oxford English Dictionary defines Clicktivism as "the use of social media and other online methods to promote a cause" (www.clicktivist.org/what-is-clicktivism).

Corporate Citizenship and VSO (2011) 'Corporate Skills-based Volunteering: A Research Study', unpublished, London: VSO

Dekker, P. and Halman, L. (eds) (2003) The Values of Volunteering: Cross-cultural Perspectives, New York NY and London: Kluwer Academic/Plenum

Devereux, P. (2010) International Volunteers: Cheap Help or Transformational Solidarity Toward Sustainable Development, Perth: Murdoch University

Devereux, P. (2008) 'International Volunteering for Development and Sustainability: Outdated Paternalism or a Radical Response to Globalisation?', Development in Practice 18.3: 357-70

Ellis Paine, A.; Ockenden, N. and Stuart, J.

(2012) 'Volunteers in Hybrid Organizations: A Marginalised Majority?', in D. Billis (ed.), Hybrid Organizations and the Third Sector: Challenges for Practice, Theory and Policy, New York NY: Palgrave Macmillan Freire, P. (1970) Pedagogy of the Oppressed, New York NY: Continuum

FSG, Pfizer and Brookings (2007) Volunteering for Impact: Best Practices in International Corporate Volunteering, www.brookings.edu/ /media/Research/Files/ Papers/2007/9/volunteering/ICV_Study_ Backgrounder.PDF (accessed June 2012)

Fyfe, N. and Milligan, C. (2003) 'Out of the Shadows: Exploring Contemporary Geographies of Voluntarism', Progress in Human Geography 27.4: 397-413

Guttentag, D.A. (2009) 'The Possible Negative Outcomes of Volunteer Tourism', International Fournal of Tourism Research 11.6: 537-61 
Haddad, L.; Lindstrom, J. and Pinto, Y. (2010) 'The Sorry State of M\&E in Agriculture: Can Peoplecentred Approaches Help?', IDS Bulletin 41.6: 6-25

Handy, F.; Cnaan, R.A.; Brudney, J.L.; Ascoli, U.; Meijs, L.C.P.M. and Ranade, S. (2000) 'Public Perception of "Who is a Volunteer?": An Examination of the Net-cost Approach from a Cross-cultural Perspective', Voluntas 11.1: 45-65

Hustinx, L. (2010) 'Institutional Individualized Volunteering: Toward a Late Modern

Re Construction', fournal of Civil Society, Special Issue

Hvenmark, J. and von Essen, J. (2010) 'A Civic Trinity in Transformation? - Changing Patterns and Perspectives on Membership, Volunteering, and Citizenship in Swedish Civil Society', paper submitted to the ninth international conference of the International Society for Third Sector Research, Kadir Has University, Istanbul, 7-10 July 2010

Jones, A. (2008) 'The Rise of Global Work', Transactions of the Institute for British Geographers 33.1: 12-26

Jones, A. (2005) 'Assessing International Youth Service Programmes in Two Low-income Countries', Voluntary Action 7.2: 7-100

Jones, E. and Gaventa, J. (2002) Concepts of Citizenship: A Review, IDS Development Bibliography 19, Brighton: IDS

Lopez Franco, E. and Shahrokh, T. (2012) 'Literature Review to Inform the Design of Valuing Volunteering', unpublished, Brighton: IDS

Lough, B. and Matthews, L. (2013) Measuring and Conveying the Added Value of International Volunteering, Forum Discussion Paper, www.france-volontaires. org/IMG/pdf/ivco2013_measuring_and_ conveying_the_added_value_of_international_ volunteering_lough.pdf (accessed May 2014)

Lough, B.; Moore McBride, A.; Sherraden, M. and O’Hara, K. (2012) 'Capacity Building Contributions of Short-term International Volunteers', paper presented for the tenth international conference of the International Society for Third Sector Research, Sienna, 10-13 July 2012

Lukka, P. and Ellis, A. (2001) 'An Exclusive Construct? Exploring Different Cultural Concepts of Volunteering', Voluntary Action 3.3: 87-109

Meijs, L. and Brudney, J. (2007) 'Winning Volunteer Scenarios: The Soul of a New Machine', International Fournal of Volunteer Administration XXIV.6: 68-79

Moore McBride, A. and Daftary, D. (2005) International Service: History and Forms, Pitfalls and
Potential, Center for Social Development Working Paper, St Louis Missouri MO: Washington University

Open Forum for CSO Development Effectiveness (2011) Siem Reap Consensus on the International Framework on CSO Development Effectiveness, Brussels: Open Forum for CSO Development Effectiveness Palacios, C.M. (2010) 'Volunteer Tourism, Development and Education in a Postcolonial World: Conceiving Global Connections Beyond Aid', Journal of Sustainable Tourism 18.7: 861-78

Patel, L.; Perold, H.; Mohamed, S. and Carapinha, R. (2007) Five-country Study on Service and Volunteering in Southern Africa, Johannesburg: VOSESA

Perold, H.; Mavungu, E.; Cronin, K.; Graham, L.; Learnmore, M. and Lough, B. (2011) International Voluntary Service in SADC: Host Organisation Perspectives from Mozambique and Tanzania, Johannesburg: VOSESA

Pinkau, I. (1981) 'A Comparative Evaluation of Volunteer Development Services', in D.H. Smith and F. Elkin (eds), Volunteers, Voluntary Associations and Development, Leiden, Netherlands: E.J. Brill

Popazzi, L. (2004) 'Returning Home: The Impact of International Volunteering on Kenyan Civil Society', final report for MSc Development Management, unpublished Scott-Smith, T. (2011) External Review of VSO's Youth for Development (YfD) Programme, London: VSO Sheard, J. (1995) 'From Lady Bountiful to Active Citizen: Volunteering and the Voluntary Sector', in J. Davis Smith, C. Rochester and R. Hedley (eds), An Introduction to the Voluntary Sector, London: Routledge

Sherraden, M.S.; Stringham, J.; Sow, S.C. and Moore McBride, A. (2006) The Forms and Structure of International Voluntary Service, CSD Working Paper, St Louis Missouri MO: Washington University

Simpson, K. (2004) "'Doing Development": The Gap Year, Volunteer-tourists and a Popular Practice of Development', Fournal of International Development 16: 681-92

Thornbecke, E. (2006) The Evolution of the Development Doctrine: 1950-2005, UNU-WIDER Research Paper 2006/155, Vienna: United Nations University UNGA (2014) The Road to Dignity by 2030: Ending Poverty, Transforming All Lives and Protecting the Planet: Synthesis Report of the Secretary General on the Post2015 Sustainable Development Agenda, New York NY: United Nations

UNV (2014) 'Section 6, from Rio+20 to Post 2015: Volunteerism, Civic Engagement and the Post 
2015 Agenda', in State of Civil Society Report 2014: Reimagining Global Governance, Johannesburg: GIVICUS

UNV (2011a) State of the World's Volunteerism Report: Universal Values for Global Wellbeing, New York NY: United Nations Volunteers
UNV (2011b) Assessing the Contribution of Volunteering to Development: A Participatory Methodology. Handbook for UN Volunteers, Programme Officers and Managers, New York NY: UNV Evaluation Unit 